\title{
피열연골내전술
}

전북대학교 의과대학 이비인후과학교실

홍기환 · 양윤수 · 김중호

\section{Arytenoid Adduction}

\author{
Ki Hwan Hong, MD, Yoon Soo Yang, MD and Joong Ho Kim, MD \\ Department of Otolaryngology-Head and Neck Surgery, Medical School, \\ Chonbuk National University, Chonbuk, Korea
}

\section{서 론}

일측 성대마비는 발성시 마비성대의 내전장애에 의 해 양측 성대의 완전한 접촉이 안되어 적절한 성문하압 을 형성하지 못하므로서 성대점막의 진동을 유발하지 못하여 음성의 변화를 초래한다. 또한 신경마비에 의한 긴장도의 감소로 막성성대의 중간부가 휘면서 역시 적 절한 성문하압을 형성하지 못하며 정상측 성대와의 높 이차이에 의한 성대점막의 불완전한 접촉에 의해 음성 의 변화가 온다. 이러한 일측 성대마비시 마비성대를 내 전시키기 위한 방법에는 성대내 주사법, 제 1 형 갑상연 골 성형술, 피열연골내전술 그리고 피열연골고정술 등 많은 술식이 소개되었다. ${ }^{1-3)}$ 일반적으로 막성성대(membranous vocal fold) 는 성대내 주사법이나 제 1 형 갑 상연골성형술에 의해 효과적으로 마비성대가 내전되나 후성문의 틈이 크거나 양측성대 사이의 높이에 차이가 있을 때에는 성대내 주사법이나 제 1 형 갑상연골성형 술은 후성문을 내전시키지 못하고 높이의 차이를 교정 시키지 못하기 때문에 술 후 만족스런 결과를 얻지 못하 는 경우가 많다. ${ }^{4)}$ 특히 윤상피열관절의 고착에 의한 경 우는 제 1 갑상연골성형술은 효과적이지 못하는데 이러

교신저자 : 홍기환, 560 180 전북 전주시 금암동 산2- 20번지 전북대학교 의과대학 이비인후과학교실 전화 : (063) 250-1990. 전송 : (063) 250- 1986

E- mail : khhong@moak.chonbuk.ac.kr
한 단점을 보완하기 위해 제 1 갑상연골성형술은 여러 변형된 술식등이 보고되었다.

피열연골 내전술은 성대사이의 틈새가 크거나 마비된 성대가 측면에 고정되어 있는 일측성 성대마비환자에 게 적용되는데 이러한 경우 원주 모양을 하고 있는 윤 상피열관절이 장축을 따라 회전운동을 하기 때문에 마 비된 성대의 높이가 높을수록 성대사이의 틈새는 커지 게 된다. 잘 알려져 있듯이 피열연골 내전술의 장점은 제 1 형 갑상연골성형술보다 마비 성대를 더욱 효과적 으로 내전시킬 수 있다는 점과 두 성대 사이에 존재할 수 있는 높이 차이를 교정할 수 있다는 점이다. ${ }^{5-7)}$ 피 열연골 내전술의 단점은 근육돌기의 위치선정 또는 긴 수술시간 등의 기술적인 문제들이나 충분히 숙지된다 면 큰 문제는 되지 않으며 대부분 특별한 합병증 없이 충분한 효과를 얻을 수 있는 경우가 많으나 성대가 굽어 있는 경우에는 효과가 없고 더욱이 성대마비와도 동반 되어 있는 경우에는 술식의 변형이나 제 1 형 갑상연골 성형술과 병합하는 등의 술식이 필요하게 된다. 그러므 로 피열연골내전술에 대한 정확한 술식과 문제점 등을 이해하여야 한다.

\section{피열연골의 해부}

피열연골내전술에 대한 근본적인 이해를 위해서는 먼 저 피열연골의 해부학적 이해와 윤상연골과 피열연골과 의 복잡한 역학적 운동이 제대로 설명되어져야 한다. ${ }^{7)}$ 
피열연골이라는 명칭은 고대 물국자 또는 물주전자처럼 방향을 잡고 있다는 점에서 유래되었다. A rytania 또는 arytaena는 그리스어로 국자, 주전자를 의미하며 Eidos 는 형(form)을 뜻하며 복합어 arytainoeide(s) 는 국자 형 또는 주전자형을 의미한다. 피열연골을 내측 또는 외측에서 보면 피열연골이 옛날식 장화와 비슷하게 생 겼다. 피열연골은 각각 1 개의 밑면과 3 개의 측면을 가 지는데 각각의 측면은 서로 만나게 되고 밑면은 오목하 고 측면은 불규칙한 모양이며 크기가 서로 다르다. 피 열연골의 측면은 내측, 후측 및 전외측으로 구성되며 내 측과 전외측면이 결합된 밑면에서는 전방, 외측방으로 돌출되어 점점 가늘어지는 구조물이 발견된다. 뒷면의 하방으로부터 후방으로의 돌출은 넓고 무디며 두꺼운 구조물로서 근육돌기로 알려져 있다. 피열연골의 전,외 측면은 2 개의 동과 와를 갖는다. 윗쪽으로는 가장 큰 삼 각형와가 있고 아래 쪽으로는 직사각형와가 있다. 각각 의 이름에 의해 유추해보면 밑면의 오목함은 상대적으 로 길고 좁다. 직사각형와는 근육돌기와 성대돌기 모두 를 만입시킨다. 만약 하나가 근육돌기의 내측. 정중수 직에서 시작되는 선을 향하고 근육돌기의 장축을 따른 다면, 선은 성대돌기를 통과할 것이다. ${ }^{8)}$ 각각 윤상피열 연골면의 단축에 상응하는 피열연골 관절면의 오목곡 선과 함께 이러한 사실을 이해하고 있는 것은 피열연골 운동의 기전을 이해하는데 매우 중요하다.

피열연골이 위치하는 윤상연골면은 후면에서 볼록하 게 구부러져 있고 타원형의 모양으로 윤상면은 외측, 전 측, 후측으로 경사져 있다. 윤상피열연골면의 장축은 윤 상연골의 후방. 측방 상방의 가장자리를 따라 지나며 피열연골 관절면의 횡단길이보다 장축의 길이가 크기 때문에 윤상연골면의 장축을 따라 피열연골의 활주운 동(gliding) 은 가능하다. 이러한 활주 운동은 강력한 후 두폐쇄시에 사용되어진다. 그러나 실제 윤상연골면의 장 축을 따른 활주운동이 주된 운동이라 할지라도 피열연 골의 또 다른 실제 운동은 윤상연골면의 단축을 따르는 내· 외측 회전운동(rotation) 및 전· 후방 흔들림운동 (rocking) 이며 흔들림 운동이란 수직적이면서 전. 후 방으로의 움직임 즉 흔들의자와 같은 운동을 의미한다. 볼록하게 구부러진 면 위에서의 활주, 회전 및 흔들림
운동들은 각각 개별적인 운동이 아니라 어느정도 서로 연관되어져 있어 동시에 일어나는 운동들로서 전. 후방, 내. 외측으로 뿐만 아니라 수직적 위치 변화가 동시에 초래하게 된다. 윤상연골면을 고려한다면 각각의 운동 에서 피열연골이 앞쪽으로 움직일 때 성대돌기는 아래 로 이동하고 근육돌기는 위로 올라간다. 즉 후방으로 활 주할 때는 성대돌기는 올라가고 근육돌기는 내려가며 후방으로의 흠들림시 성대돌기는 높아지고 전방으로 흔 들림시 성대돌기는 낮아진다. 내· 회전운동도 성대돌기 의 높이에 변화를 줄 수 있겠지만 그 정도는 매우 미비 할 것으로 예상된다. 실제 피열연골의 이러한 흔들림 운 동은 회전운동과 매우 비슷한 유사성을 지니며 회전운 동이라는 용어의 도입은 많은 문제를 야기시켰지만 임 상적으로 매우 중요하다. 후두경을 통해 후두를 위에서 볼 때, 수직적 변화는 잘 평가 할 수 없는 반면 내· 외 측운동은 강조되어 진다. 그러나 피열연골의 수직적 이 동은 내· 외측 이동과 더불어 동시에 일어나는 매우 중 요한 운동인 것이다. 성대를 관찰할 때 피열연골이 전 방 하방으로 움직임에 따라 부가적인 운동인 내- 외 측으로 움직이는 것이 관찰된다. 윤상면은 외측, 전측, 후측으로 경사져 있기 때문에 피열연골이 전방 하방 으로 운동을 하는 동안 성대는 외전된 상태이며 피열연 골이 후방. 상방으로 움직일 때 성대는 바같쪽으로 외 전된 상태이지만 전,하방운동보다는 내전된 상태이다. 결과적으로 성대가 내전하는 동안 성대의 후방 $1 \beta$ 의 위치는 중간 $1 \beta$ 보다 높으며 중간 $1 \beta$ 은 전방 $1 \beta$ 보다 높다. 이러한 역학적 운동을 배경으로 발성 및 호흡시 의 성대의 위치 및 높이를 고려한다면 정상 호흡시 성 대는 전방 활주운동 및 외측 회전운동에 의해 성대돌기 는 낮아지게 되고 발성시는 후방활주운동 및 내전 회전 운동에 의해 성대돌기는 높아지며 전방 흔들림 운동에 의해 성대돌기는 낮아질 수 있지만 주된 운동은 후방활 주로 운동이므로 전체적으로 성대돌기는 상승된다.

\section{술 식}

마취는 제 1 형 갑상연골성형술와 동일한 방법으로 술 전 진정과 국소마취를 실시하거나 혹은 전신마취하에 


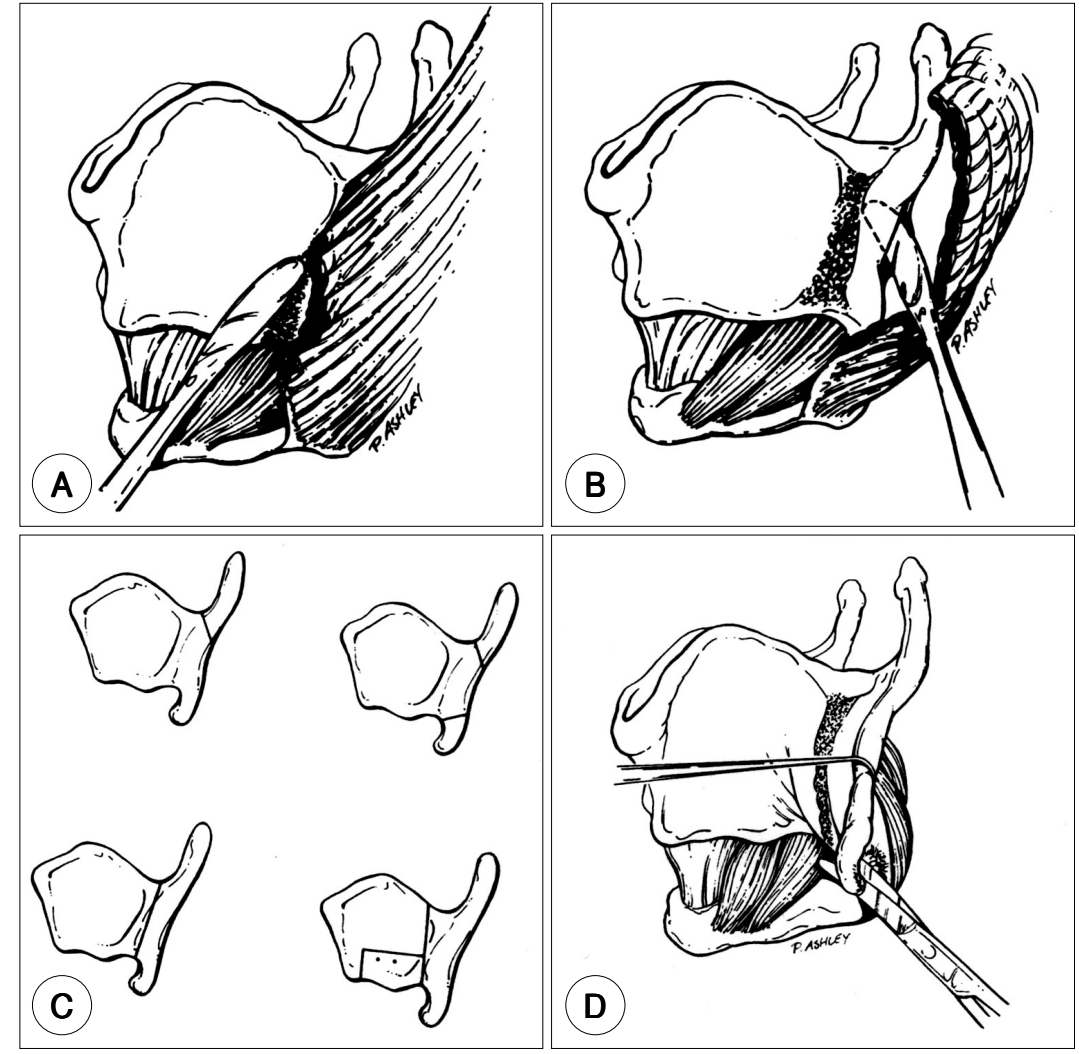

Fig. 1. Arytenoid adduction, A-D. A : The thyropharyngeus muscle is separated from the ala of the tyroid cartilage. B : The inner perichondrium is elevated in order to prevent entrance into the aimay. $C$ : The transection of the thyroid cartilage in one of the patterns. D : Simple anterior retraction of the thyroid cartolage for exposing the cricothyroid joint surface.
실시한다. 피부절개선은 성대 높이에서 수평으로 제 1 형 갑상연골 성형술보다는 1 2 cm 정도 측면으로 더 연장한다. 갑상연골판의 후연을 노출시키기 위해선 보 통 흉골설골근의 $1 / 2$ 이상을 절개해야 하며 작은 갈고 리로 갑상연골 후연을 앞쪽으로 견인하고 후연에 인접 한 갑상인두근의 부착부위에 절개를 가한다. 이 절개선 으로부터 아래쪽으로 갑상연골익의 후측 끝면까지 연 골막상부로 근육을 거상시킨다 Fig. 1).

갑상연골 후연에 도달한 후 연골과 내측연골막을 박 리시키고 더 이래쪽으로 윤상갑상관절을 탈구시킨다 Fig. 1). 이 관절이 너무 아래쪽에 위치하여 연조직에 손상 을 많이 입혀야 관절에 닿을 수 있는 경우 윤상연골위 의 관절면을 확인할 수 있다면 갑상연골 하익의 근위부 를 자르기도 한다. 후연에서 절개한 연골부위는 충분한 수술시야 확보를 위해 제거하고 이 곳을 통해 피열연골 의 근육돌기가 상방 그리고 후방에서 확인된다. 윤상피 열관절의 전방에 위치하는 윤상연골의 작은 돌기가 촉
진상 근육돌기로 오인될 수 있으므로 주의해야 하며 주 위의 연조직을 박리한 후 근위부를 절단하게 되는데 이 는 견인시 성대의 회전이 더 잘 이루어지게 하기 위함 이다. 근육돌기는 일정한 모양을 가진 근육층 아래에 숨 겨져 있기 때문에 확인이 어렵다. 근육돌기를 확인하는 네가지 방법은 다음과 같다(Fig. 2). 첫째, 근육돌기는 항상 성대의 높이에 위치하게 된다. 따라서 갑상연골판 아래쪽으로 후연까지 성대가 위치하는 부위에 가상의 선을 그림으로써 근육돌기를 찾기 위한 기준선으로 사 용할 수 있다. 둘째, 근육돌기는 윤상갑상관절의 상연으 로부터 $1 \mathrm{~cm}$ 이내에 위치한다. 셋째, 근육돌기는 원래 윤상연골의 상연에 위치한다. 미세 가위의 끝으로 근육 층을 파고 들어가거나 둔하게 박리시키기 시작할 때 미 세 골막박리기로 박리하는 부위 아래쪽에 연골이 있는 지를 확인하는 것이 중요하며 연골이 없는 부위의 연조 직을 자르고 들어갈 경우 기도내로 들어가서 수술시야 를 오염시키고 다른 합병증을 초래할 수 있기 때문이다. 


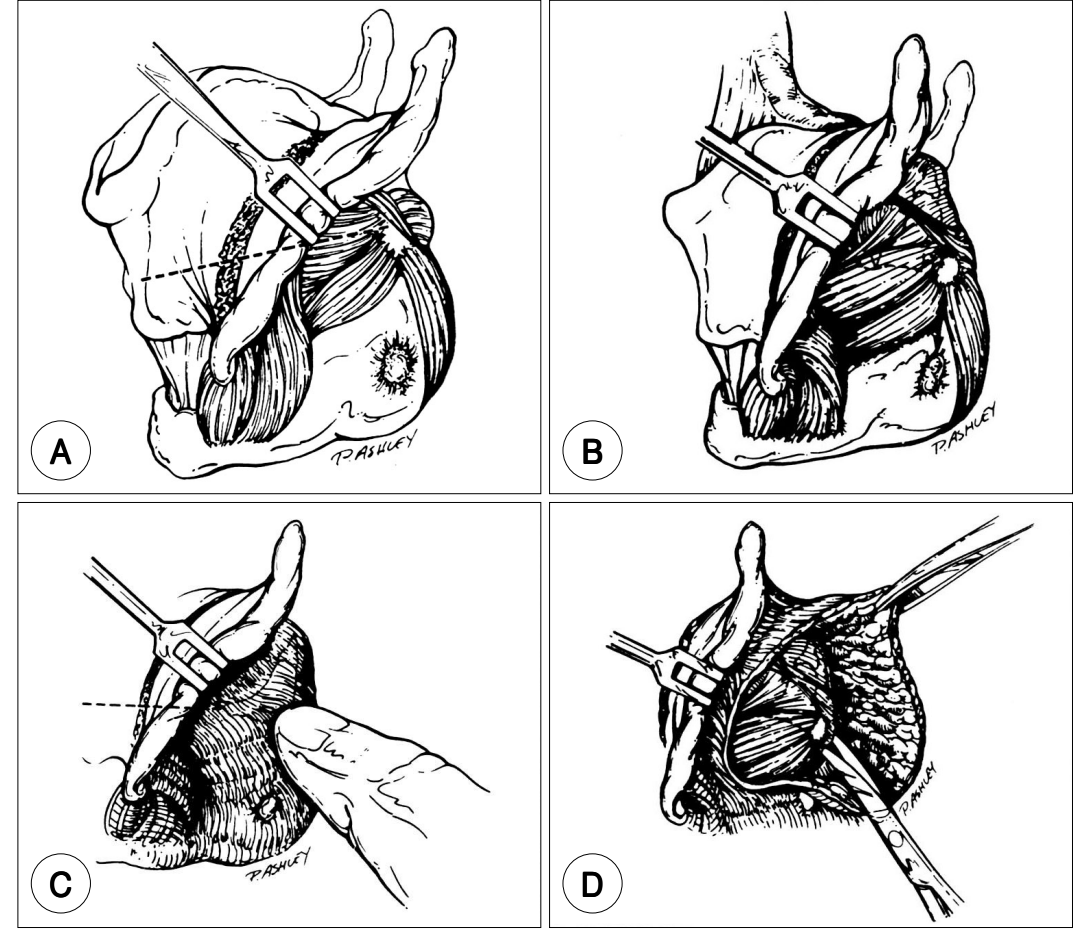

Fig. 2. Arytenoid adduction, E-H. E : The muscular process of the aryteoid is located at the level of the vocal cord. $\mathrm{F}:$ The distance of the cricoarytenoid joint from cricothyrpoid joint is less than $1 \mathrm{~cm}$. $\mathrm{G}$ : The muscular process can often be identified by palpation. $\mathrm{H}$ : The posterior cricoarytenoid muscle fibers are divided, and the cricoarytenoid joint is entered.
넷째로 절개할 부위를 술자의 검지손가락으로 조심스 럽게 촉지하면 작은 쌀알 크기의 근육돌기가 만져질 수 있다. 하지만 이때 촉지하는 손가락이 시야를 완전히 가 릴 수도 있으므로 연조직박리를 시작하기 전에 돌기가 어디에 위치하는지에 대한 정확한 감각을 가지고 있어 야 한다. 또한 수술 내내 갑상연골익을 견인하므로써 해 부학적인 구조물들의 관계를 파악할 수 있으므로 수술 내내 일정하게 견인하고 있도록 주의해야 한다. 이상와 의 점막은 근육돌기보다 아래쪽에 위치한다. 후윤상피 열근으로부터 융기되어 기도와 수술시야를 분리해주는 점막은 매우 얇아 호흡시 생기는 기류와 같이 홉흡에 따 라 요동치는 모습을 보이기도 한다. 근육돌기를 찾아나 가는 과정은 윤상갑상관절이나 그 하방으로부터 시작해 야 하며 연조직이 얇고 딱딱한 바닥층이 없는 성대부위 상방으로 올라가서는 안된다. 근육돌기를 찾는데 너무 많은 시간이 소요될 경우 성대부위에 부종이 생기고 수 술 중 음성조절에 문제가 생길 수도 있다.

윤상피열연골 관절은 흰색의 반짝거리는 난형의 구조 물로서 아래쪽으로 기울어져 있는 모양이다. 이 관절을
열면 근육돌기를 통해 단단한 봉합을 하기가 더 용이해 지고 관절면을 통해 상부쪽으로 봉합을 실시해 장기간 의 긴장을 유지할 수 있도록 충분한 근육과 연골을 붙 잡고 묶어주게 된다(Fig. 3). 성대사이의 틈새가 커서 내전을 더 많이 시켜야 할 경우에는 회전을 더 자유롭 게 할 수 있도록 후방으로 측면을 따라 관절절개를 더 욱 연장하고 봉합 또한 더욱 후외측으로 실시하게 된다. 그러나 지나치게 후방으로 관절절개를 많이 하면 성대 를 짧게 만들 수 있고 봉합을 지나치게 외측으로 하게 되면 성대가 정중선을 가로질러 내측으로 너무 많이 이 동되어 거칠고 힘들어간 목소리가 나게 된다. 근육돌기 의 견인방향은 매우 중요하다. 대개 갑상연골판의 앞쪽 $1 / 3$ 및 $1 / 2$ 지점 두군데에 위치시키는 것이 좋다. 여성 에서는 갑상연골판을 전내측방으로 견인하면서 근육돌 기를 묶은 봉합사를 무딘 바늘을 사용하여 갑상연골판 을 통과하게 할 수 있으며 남성에서는 미세한 burr를 사용하여 구멍을 만들 수도 있다. 구멍은 근육돌기 쪽으 로 향하게 만들어야 하며 바늘을 구멍에 넣어 갑상연골 판의 내면으로 거의 평행하게 갑상연골의 후연에서 바 


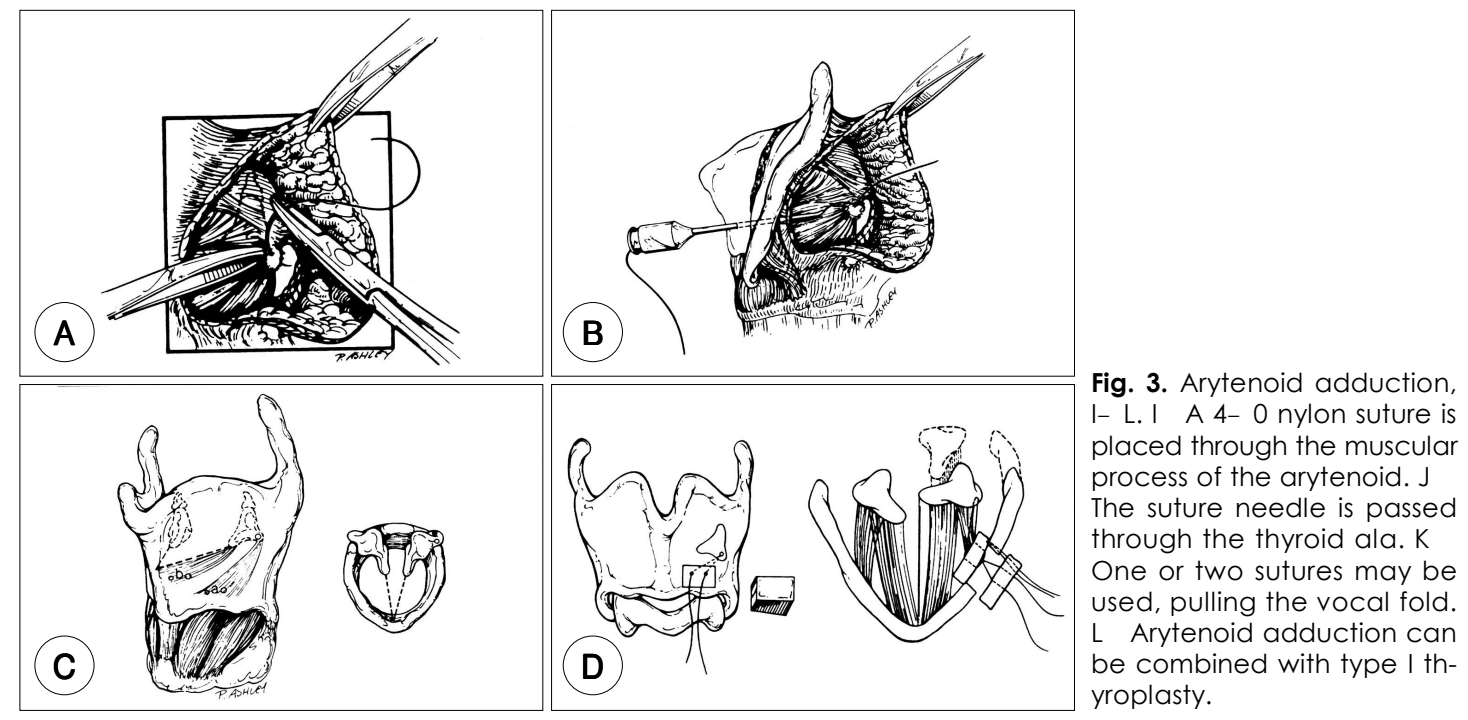

늘의 끝이 보일때까지 통과시키고 nylon을 바늘 안쪽으 로 들어가게 한다. 또 다른 방법으로는 각각 갑상피열 근과 윤상피열근의 기능을 자극하는 두쌍의 구멍을 만 들어 주는 방법이 있다. 이 방법은 서로 가까이 붙어 있 는 네게의 구멍을 만드는 것으로 구멍 사이의 연골부위 를 부서지기 쉽게 하고 suture의 장력에 견디는 힘을 약하게 할 수가 있으므로 적절한 거리를 두고 구멍들을 만들어야 한다.

수술중 성대내전의 정도를 확인하기 위해서는 비점 막 표면마취 후 연성 후두경을 비강을 통해 삽입해 시 험동작 도중 후두운동의 변화를 내시경으로 관찰할 수 있다. 술 중 조절은 어깨 아래에 위치시겼던 베개를 제 거하여 발성하기 더 쉬운 자세로 만들어 주는 것이 좋 다. 환자가 만족할 만한 음성이 나오고 성대사이의 틈 새가 보이지 않게 되면 봉합사를 $50 \mathrm{~g}$ 이나 그 이상의 장력으로 묶어두는 시점에서 수술을 종료할 수 있다. 일 반적으로 단단하게 묶여지는 봉합의 경우 가해지는 힘 은 약 100 200 g 정도이다. 만일 봉합견인에 의한 음 성의 개선이 만족할 만하지 않다면 그 원인과 해결책을 찾아보아야 한다. 술 후에도 남아있게 되는 경도의 애 성을 일으킬만한 가능한 인자들은 부적절한 내전에 의 한 성문의 불완전 폐쇄, 성대위축이나 성대변연이 굽어 서 생기는 성문의 불완전 폐쇄, 성대에 가해지는 장력
이 부적절한 장력, 술 전 혹은 술 후 성대부종, 마비성대 를 지나치게 내전시킨 경우나 정상성대의 과보상내전에 의해 생기는 성문의 팽팽한 폐쇄 등이며 그 외에도 반 흔조직 혹은 성대구증 등의 다른 병리학적 조건들이 있 을 수 있겠다. 봉합을 더 세게 견인하여도 성대사이의 틈새나 음성의 호전이 없을 경우에는 제 1 갑상연골 성 형술 등의 술식과도 병합하여야 최상의 결과를 얻을 수 있다.

\section{수술시 고려사항}

성대는 후두경을 통해 상부로부터 쉽게 관찰된다. 상 부로부터의 관찰로 인해 성대마비시 마비의 위치는 정 중위, 부정중위 및 중간위 등으로만 표현되며 높이의 차 이에 대해서는 대부분 관찰할 수 없다고 보고하였다. 그 러나 내시경의 발달로 어느정도 높이의 차이를 예측할 수 있다. 위의 역학적 운동을 배경으로 설명한다면 정 중위 혹은 부정중위 마비에서는 마비된 피열연골이 윤 상연골위에서 후방 활주된 상태로 고정되며 호흡시는 정상 피열연골이 전방 활주운동에 의해 외측, 하방으로 이동하기 때문에 마비성대가 높게 위치한다.반면에 발 성시에는 정상성대가 후방 활주운동에 의해 상승한 상 태에서 전방 흔들림에 의해 약간 성대돌기가 낮아져도 
전체적으로 상승한 상태이므로 마비된 성대와 비슷하게 위치하거나 정상성대의 전방 흔들림에 의해 마비성대가 약간 높게 위치할 수 있다. 그러나 중간위 마비시에는 마비된 피열연골이 윤상연골위에서 전방 활주로운동에 의해 하강한 상태로 고정되며 호흡시 정상 피열연골도 전방 활주로운동에 의해 하방으로 이동하기 때문에 마 비성대는 정상성대와 비슷하게 위치하며, 발성시에는 정 상성대가 후방 활주로운동에 의해 상승한 상태로 위치 하기 때문에 마비된 성대에 비해 높게 위치한다. 또한 마비 성대는 마비된 피열연골의 모양에 따라 높이가 달 라진다. 후두경에 의해 성대를 상부에서 보면 마비된 피 열연골은 앞. 뒤 혹은 내. 외측으로 기울려 있게 보인 다. 이러한 모양을 윤상연골면에서의 운동을 고려한다 면 앞. 뒤로의 기울림은 흔들림 운동을 의미하고 내. 외로의 기울림은 회전운동을 의미한다. 회전운동은 성대 돌기의 높이에 많은 영향이 없으므로 앞. 뒤로의 기울 림을 고려하면 앞으로의 기울림은 결과적으로 전방 흔 들림 운동을 의미하므로 성대돌기가 낮아지고 후방으 로의 기울림은 후방 흔들림 운동을 의미하므로 성대돌 기가 높아지게 된다. 마비된 피열연골의 모양이 앞으로 기울려 있으면 뒤로 기울린 모양보다 성대돌기가 낮아 진다. 그러므로 수술의 선택에 있어서 이러한 점을 종 합적으로 고려하여야 한다. Isshiki에 의한 제 1 형 갑상 연골성형술은 마비된 성대의 막성부분을 오직 내측으로 만 이동시키므로 양측 성대사이의 높이의 차이 특히 마 비시 높아진 성대를 교정하지 못하며 피열연골내전술은 피열연골의 근돌기를 잡아당기므로서 성대돌기를 효과 적으로 내전시켜 후성문 틈이 큰 경우 효과적이며 갑상 피열근과 측윤상피열근 방향으로 잡아당기므로서 마비 성대를 낮게 하여 정상성대와의 높이차이를 교정한다고 알려져 왔다. 그러나 실제 마비성대의 높이 변화에 대 한 다양한 보고에 의해 과연 피열연골 내전술이 효과적 인가는 의문점으로 남아있다. 이론적으로 보면 일측성대 마비시 마비성대가 발성시 정상 성대에 비해 높게 위치 하면 피열연골내전술에 의해 마비성대를 적절히 낮게 되며 발성시 정상 성대와 같은 높이라면 높이 교정은 필요없게 되므로 오히려 피열연골내전술이 마비성대를 낮게하는 결과를 초래할 것이다. 반대로 발성시 마비성 대가 정상성대에 비해 낮게 위치한다면 피열연골내전
술이 마비성대의 높이를 더욱 낮게 하여 높이의 변화를 악화시킬 것이다. 그러므로 성대마비시 높이의 변화에 대한 정확한 이해가 수술을 결정하는데 많은 도움이 될 것이다.

또한 Hong 등 ${ }^{8)}$ 의 결과를 토대로 수술의 종류를 선 택하여야 하는데 마비성대가 정중위 혹은 부정중위이면 서 피열연골이 body 형 혹은 process형인 경우에는 발 성시 정상성대에 비해 마비성대가 높게 위치하면 피열 연골내전술에 의해 마비성대가 낮아지고 적절히 내전시 키므로 효과적일 것이며 높이가 비슷한 경우에는 마비 성대를 내전만 시키면 되기 때문에 제 1 형 갑상연골성 형술이 효과적일 것이다. Tip형이나 no형이면서 마비 성대가 정상성대에 비해 비슷하게 위치하면 제 1 형 갑 상연골성형술을, 성대높이가 오히려 낮으면 피열연골내 전술을 시행해서는 안되고 제 1 형 갑상연골성형술을 시 행할 수도 있겠다. 요약하면 일측 성대마비시 마비성대 의 높이는 일관적이지 않으며 마비성대의 위치, 피열연 골의 모양 등에 의해 개체간에서 매우 다양하게 나타나 며 이러한 사항을 고려하여 향후 일측성대마비에 대한 수술의 종류가 결정되어져야 하겠다.

\section{고 안}

성대마비는 반회후두신경의 기능부전 결과로 이에 따 른 음성의 변화는 발성시 마비된 성대의 내전장애에 의 해 성문이 지속적으로 열려있기 때문이다. 이러한 점을 교정하기 위하여 성대내 주사법, 제 1 형 갑상연골 성형 술, 피열연골내전술 그리고 피열연골 내측고정술 등이 소개되어왔다. 일반적으로 시행되는 제 1 형 갑상연골성 형술은 후성문을 내전시키지 못하고 높이의 차이를 교 정시키지 못하기 때문에 술 후 만족스런 결과를 얻지 못 하는 경우가 많다. 이러한 단점을 보완하기 위해 갑상 연골의 내연골막을 절개하거나 큰 silicone block을 사 용하여 성대돌기를 눌러주지만 T anaka ${ }^{2)}$ 및 Kojima ${ }^{4}$ 에 의하면 성대돌기가 내전되지 않아 후성문이 큰 경우 에는 효과적이지 못하다고 보고하였다. 이러한 단점으로 인해 고안된 피열연골내전술도 막성성대를 직접 내전 시키지 못하고 단독으로는 음성의 호전이 불완전한 경 우가 많아 제 1 형 갑상연골 성형술과 동시에 시행하는 
경우가 대부분이며 동시에 시행한다해도 후성문의 틈 이 크거나 마비성대가 중간위로 위치한 경우는 효과적 이지 못한 경우가 많다. 또한 마비 성대가 정상에 비해 높게 위치한 상태인 경우 효과적이지만 만약 마비된 성 대가 정상에 비해 낮거나 같은 위치이면 피열연골내전 에 의해 오히려 마비성대의 높이가 정상에 비해 오히려 악화되어 만족스런 음성을 얻을 수 없게 된다.

일반적으로 일측성대마비시는 상후두신경은 정상이므 로 마비성대는 반회신경마비에 의해 내전은 안되지만 윤상갑상근의 정상적인 수축에 의해 피열연골이 내전 된 상태로 고정되며 성대도 높게 위치한다고 알려져 왔 다. ${ }^{9-12)}$ 실제 문헌고찰에 의하면 대부분의 문헌에서 마 비성대는 정상측 성대에 비해 발성시 높게 위치한다고 보고되어져 왔다. 특히 Letson ${ }^{7)}$ 은 호흡시 정상성대의 성대돌기가 높게 위치하고 발성시는 정상성대의 성대 돌기가 마비측에 비해 낮게 위치한다고 보고하였다. 이 러한 보고들에 의해 피열연골내전술은 피열연골의 근 돌기를 측윤상피열근의 활동과 같은 방향으로 당기기 때문에 성대돌기를 내전시킴과 동시에 마비성대를 낮 게 한다고 알려져 왔다. 그러나 윤상피열관절이 고정된 경우는 근돌기를 견인해도 잘 내전되지 않는 경우가 있 어 윤상피열관절을 일부를 노출시키는데 너무 노출시킬 경우 근돌기를 견일할 때 피열연골이 전방으로 끌려 오 히려 성대가 짧아질 수 있으며 피열연골이 전방으로 견 인되지 않는다 해도 성대돌기만 내전되어 오히려 후성 문이 더 넓어지는 경우가 있을 수 있다. 또한 피열연골 내전술은 막성성대를 직접 내전시키지 못하기 때문에 단독으로는 음성의 호전이 불완전한 경우가 많아 제 1 갑상연골 성형술과 동시에 시행하는 경우가 대부분이 다. $^{13)}$ 그러나 동시에 시행한다해도 피열연골을 직접 내 전시키지는 못하므로 후성문의 틈이 크거나 마비성대가 중간위로 위치한 경우는 효과적이지 못한 경우가 많다. 실제 피열연골내전술은 마비 성대가 정상에 비해 높게 위치한 상태인 경우 효과적이지만 만약 마비된 성대가 정상에 비해 낮거나 같은 위치이면 피열연골내전에 의
해 오히려 마비성대의 높이가 정상에 비해 오히려 악화 되어 만족스런 음성을 얻을 수 없게 된다. ${ }^{14)}$

중심 단어 : 피열연골내전술.

\section{REFERENCES}

1) Isshiki N. Phonosurgery, theory and practice. SpringerVerlag-Tokyo;1989. p.109-29.

2) Tanaka S, Tanabe M, Minoyama M, Iwanaga M. Thyroplasty for improvement of posterior glottis incompetence. J Jpn Bronchoesophagol Soc 1996;47:297-9.

3) Bielamowicz S, Berke GS. An improved method of medialization laryngoplasty using a three-sided thyroplasty window. Laryngoscope 1995;105:537-9.

4) Kojima H, Hirano S, Shoji K, Isshiki N. Anatomic study for posterior medialization laryngoplasty. Ann Otol Rhinol Laryngol 1999;108:373-7.

5) Isshiki N, Tanabe M, Sawada M. Arytenoid adduction for unilateral vocal cord paralysis. Arch Otolaryngol 1978; 104:555-8.

6) Slavit DH, Maragos NE. Physiologic assessment of arytenoid adduction. Ann Otol Rhinol Laryngol 1992;101: $321-7$.

7) Leston Jr JA, Tatchell R. Arytenoid movement. Professional voice the science and art of clinical care $2 \mathrm{nd}$ ed. San Diago-London: Singular publishing group;1997. p.131-45.

8) Hong KH, Jung KS. Arytenoid appearance and vertical level difference between the paralyzed and innervated vocal folds. Laryngoscope 2001;111:227-32.

9) Isshiki N, Ishikawa T. Diagnostic value of tomography in unilateral vocal cord paralysis. Laryngoscope 1976; 86:1573-8.

10) Woodson GE, Hengesteg A, Rosen CA, Yeung D, Chen $\mathrm{N}$. Changes in length And spatial orientation of the vocal fold with arytenoid adduction in cadaver larynges. Ann Otol Rhinol Laryngol 1997;106:552-7.

11) Noordzij JP, Perrault DF, Woo P. Biomechanics of arytenoid adduction surgery in an ex vivo canine model. Ann Otol Rhinol Laryngol 1998;107:454-61.

12) Baken RJ, Isshiki N. Arytenoid displacement by simulated intrinsic laryngeal muscle contraction. Folia Phoniatrica 1977;29:206-16.

13) Netterville JL, Stone RE, Luken ES, Civantos FJ, Ossoff RH. Silastic medialization and arytenoid adduction: The Vanderbilt experience. A Review of 116 phonosurgical procedures. Ann Otol Rhinol Laryngol 1993;102:413-24.

14) Hong $\mathrm{KH}$, Kim JH, Kim HK. Anterior and posterior medialization (APM) thyroplasty. Laryngoscope 2001; 111:1406-10. 